\title{
The Influence of Experimental Conditions on the Formation of ZnO Fibers by Electrospinning ${ }^{\dagger}$
}

\author{
Mira Ristić, ${ }^{*}$ Marijan Marciuš, Željka Petrović, Mile Ivanda, and Svetozar Musić \\ Ruđer Bošković Institute, Bijenička cesta 54, P.O. Box 180, HR-10002, Zagreb, Croatia \\ RECEIVED DECEMBER 16, 2013; REVISED APRIL 11, 2014; ACCEPTED MAY 9, 2014

\begin{abstract}
The influence of experimental conditions on the formation of $\mathrm{ZnO}$ fibers by electrospinning has been investigated. The electrospinning of a viscous suspension containing polyvinylpyrrolidone and zinc acetate in $\mathrm{C}_{2} \mathrm{H}_{5} \mathrm{OH} / \mathrm{H}_{2} \mathrm{O}$ produced very long fibers (several hundred $\mu \mathrm{m}$ ). Upon calcination a thin deposit of precursor fibers at 400 or $500{ }^{\circ} \mathrm{C}$ for $1 \mathrm{~h}$ the fibers consisting of $\mathrm{ZnO}$ nanoparticles were obtained. On the other hand, $\mathrm{ZnO}$ fibers were not obtained upon heating a thick deposit of precursor fibers at $600{ }^{\circ} \mathrm{C}$ for $6 \mathrm{~h}$. At all three heating temperatures $\left(400,500\right.$ or $\left.600^{\circ} \mathrm{C}\right) \mathrm{ZnO}$ nanoparticles with a gradual increase in size were produced. The Raman spectrum of $\mathrm{ZnO}$ nanoparticles formed at $600{ }^{\circ} \mathrm{C}$ showed additional bands which were assigned to graphene oxide. It was suggested that in the thick deposit the organic component did not burn out completely, i.e., the residual carbon (graphite) transformed into graphene oxide for the experimental conditions applied.
\end{abstract}

Keywords: $\mathrm{ZnO}$ fibers, graphene oxide, electrospinning, electron microscopy, Raman spectroscopy, $\mathrm{X}$-ray diffraction

\section{INTRODUCTION}

In recent years many researchers have strongly focused on the synthesis of zinc oxide $(\mathrm{ZnO})$ particles and their properties due to the importance of this material in advanced technologies, for example in the manufacture of photovoltaic devices, LED's, transistors, sensors, varistors, etc. We have systematically investigated ${ }^{1-9}$ the impact of different experimental conditions on the properties of $\mathrm{ZnO}$ powders. In continuation of these works we have studied the impact of experimental conditions on the formation of $\mathrm{ZnO}$ fibers using the electrospinning method. Generally, in this electrostatic processing method the high-voltage electric field is used to form solid fibers from a fluid (solution, suspension or melt) injected through the nozzle (1 $\mathrm{mm}$ or less in diameter).

Some selected works on the $\mathrm{ZnO}$ synthesis using electrospinning will be cited herein. For example, $\mathrm{ZnO}$ nanofibers were synthesized by electrospinning and tested as sensors for $\mathrm{NO}_{2}$ and $\mathrm{CO}$ or $\mathrm{NO}$ gases. ${ }^{10,11} \mathrm{ZnO}$ nanofibers doped with $\mathrm{Cu}$ were tested ${ }^{12}$ as a sensor for $\mathrm{H}_{2} \mathrm{~S}$ and doped ${ }^{13}$ with $\mathrm{Al}$ as a sensor for $\mathrm{C}_{2} \mathrm{H}_{5} \mathrm{OH}$. The sensitivity to $\mathrm{C}_{2} \mathrm{H}_{2}$ gas of the electrospun Ni-doped $\mathrm{ZnO}$ nanofibers was investigated. ${ }^{14}$ The sensitivity of $\mathrm{ZnO}$ based sensors is influenced by the specific surface area and porosity. These properties can be optimized using the electrospinning method.
The electrical properties of FE transistors based on single $\mathrm{ZnO}$ or Ga-doped $\mathrm{ZnO}$ nanofiber were also investigated. ${ }^{15,16}$ The efficiency of organic/inorganic photovoltaic devices was improved by using the electrospun $\mathrm{ZnO}$ nanofibers. ${ }^{17}$ Electrospun nanofibers forming p-type $\mathrm{NiO} / \mathrm{n}$-type $\mathrm{ZnO}$ heterojunctions were characterized by enhanced photovoltaic activity. ${ }^{18}$ More information about the electrospinning method and its capabilities in the production of different fibers is given in the book by Ramakrishna et al. ${ }^{19}$

The synthesis of $\mathrm{ZnO}$ fibers by electrospinning depends on various factors, such as the starting zinc salt, the type of polymer or solvent, chemical concentrations, as well as the physical conditions of the experiment. In the present work some of these factors were studied with a view to obtaining more data on the formation of $\mathrm{ZnO}$ fibers by electrospinning.

\section{EXPERIMENTAL}

\section{Chemicals and Sample Preparation}

The following chemicals were used: polyvinylpyrrolidone (PVP, $\left.M_{\mathrm{w}}=1300000\right)$ supplied by Alfa Aesar $^{\mathbb{B}}$, zinc acetate dihydrate $\left(\mathrm{Zn}\left(\mathrm{CH}_{3} \mathrm{COO}\right)_{2} \cdot 2 \mathrm{H}_{2} \mathrm{O}\right)$ supplied by Kemika and absolute ethanol supplied by Carlo Erba. Twice-distilled water was prepared in own laboratory.

\footnotetext{
$\dagger$ Dedicated to Dr. Mirjana Eckert-Maksić on the occasion of her $70^{\text {th }}$ birthday.

* Author to whom correspondence should be addressed. (E-mail: ristic@irb.hr)
} 
Sample S1 was prepared as follows. $3 \mathrm{~g}$ PVP was dissolved in $50 \mathrm{ml}$ of absolute $\mathrm{C}_{2} \mathrm{H}_{5} \mathrm{OH}$ and $5 \mathrm{ml} \mathrm{H}_{2} \mathrm{O}$. This was continued by mixing at $350 \mathrm{rpm}$ and $70{ }^{\circ} \mathrm{C}$ for 2 hours. A viscous solution was obtained.

Sample S2 was prepared by dissolving $3 \mathrm{~g}$ PVP in $50 \mathrm{ml}$ of absolute $\mathrm{C}_{2} \mathrm{H}_{5} \mathrm{OH}$ and mixing at $250 \mathrm{rpm}$ and $60{ }^{\circ} \mathrm{C}$ for $2 \mathrm{~h} .1 .2 \mathrm{~g}$ of zinc acetate dihydrate was dissolved in $5 \mathrm{ml} \mathrm{H}_{2} \mathrm{O}$, then added to the ethanolic solution of PVP and additionally mixed at $250 \mathrm{rpm}$ and $60{ }^{\circ} \mathrm{C}$ for $3 \mathrm{~h}$.

The electrospun fibers (sample S2) were calcined at $400{ }^{\circ} \mathrm{C}$ for $1 \mathrm{~h}(\mathrm{~S} 2-400), 500{ }^{\circ} \mathrm{C}$ for $1 \mathrm{~h}(\mathrm{~S} 2-500)$ and $600{ }^{\circ} \mathrm{C}$ for $6 \mathrm{~h}(\mathrm{~S} 2-600)$. Calcination of the electrospun fibers was performed in the laboratory oven in air starting from room temperature and kept at the desired temperature for given period of time.

\section{Electrospinning Device and Sample Characterization}

The electrospinning device was homemade. The viscous liquid was pressed by air (15 mbar) in a glass tube capped with a nozzle (internal diameter $0.8 \mathrm{~mm}$ ). The metallic nozzle was connected to the negative terminal of power supply adjusted at $20 \mathrm{kV}$, whereas the positive one was grounded and connected with the aluminium plate sized $15 \mathrm{~cm} \times 20 \mathrm{~cm}$. In the electrospinning experiments the aluminium plate was covered with aluminium foil for collecting the electrospun material. The distance between the metallic nozzle tip and the aluminium plate was $20 \mathrm{~cm}$. The high-voltage auto-reserving power supply CZE $1000 \mathrm{R}$ manufuctured by Spellman (N.Y., USA) was used. The electrospinning unit was installed in the plexiglas tube, $100 \mathrm{~cm}$ long and $50 \mathrm{~cm}$ in diameter.

Raman spectra were recorded using a Horiba Jobin Yvon spectrometer (model T64000). The measurement temperature was regulated by a THMS600 unit manufactured by Lincam Scientific Instruments. The argon laser beam of $514.5 \mathrm{~nm}$ was used as excitation source. Also used was a Perkin-Elmer FT-IR spectrometer (model 2000). The specimen was pressed into tablets using a spectroscopically pure $\mathrm{KBr}$ matrix and a Carver press. ItalStructures XRD diffractometer (model APD 2000) was used to identify the phase composition. The shape and size of fibers (particles) were inspected with a Jeol thermal field emission scanning electron microscope (FE-SEM, model JSM-7000F). The FESEM was coupled with an Oxford Instruments EDS/ INCA 350 (energy dispersive X-ray analyzer). The inspected samples were not coated with an electrically conductive layer. Computer program ImageJ was used in processing of FE-SEM sample images to obtain particle size distributions.

\section{RESULTS AND DISCUSSION}

Figure 1 shows fibers produced by the electrospinning of a viscous PVP solution in $\mathrm{C}_{2} \mathrm{H}_{5} \mathrm{OH} / \mathrm{H}_{2} \mathrm{O}$ solvent without $\mathrm{Zn}^{2+}$ ions (sample $\mathrm{S} 1$ ).

Upon electrospinning of a viscous suspension containing PVP and $\mathrm{Zn}\left(\mathrm{CH}_{3} \mathrm{COO}\right)_{2}$ in $\mathrm{C}_{2} \mathrm{H}_{5} \mathrm{OH} / \mathrm{H}_{2} \mathrm{O}$ solvent, the fibers, several hundred $\mu \mathrm{m}$ long were produced (sample S2; Figure 2a). Figure 2b shows these fibers at higher magnification; their diameters measured between 0.220 and $0.340 \mu \mathrm{m}$. Upon their heating at $400{ }^{\circ} \mathrm{C}$ or $500{ }^{\circ} \mathrm{C}$ for $1 \mathrm{~h}$ the produced fibers consisted of uniform $\mathrm{ZnO}$ nanoparticles (Figures $2 \mathrm{c}$ and $2 \mathrm{~d}$ ). The EDS of the selected area showed the atomic ratio $\mathrm{Zn}: \mathrm{O}$ close to that of a stoichiometric $\mathrm{ZnO}$ composition (Figure $3 \mathrm{a}$ and $3 b)$. It should be mentioned that these $\mathrm{ZnO}$ fibers were produced when a thin deposit of the precursor fibers on Al foil was used (30 min of electrospinning). On the other hand, no $\mathrm{ZnO}$ fibers were obtained when a thick layer of the precursor fibers ( $25 \mathrm{~h}$ of electrospinning) was heated at $600{ }^{\circ} \mathrm{C}$ for $6 \mathrm{~h}$. After short time of electrospinning $(30 \mathrm{~min})$ the fibers were formed as a thin film on Al foil (substrate), whereas the fibers produced after a long time of electrospinning $(\sim 25 \mathrm{~h})$ were easily delaminated as thick foil. The particles produced at $600{ }^{\circ} \mathrm{C}$ are shown in Figure 4 (sample S2-600), and the size distributions of $\mathrm{ZnO}$ particles produced at 400,500 and $600{ }^{\circ} \mathrm{C}$ are shown in Figure 5. These distributions show a gradual increase in the average $\mathrm{ZnO}$ particle size with an increase in the calcination temperature. At $600{ }^{\circ} \mathrm{C}$ the sintering of the particles is also seen. The present work demonstrates that the thickness of the deposited precursor fibers (short or long time of electrospinning) plays an important role in the formation of

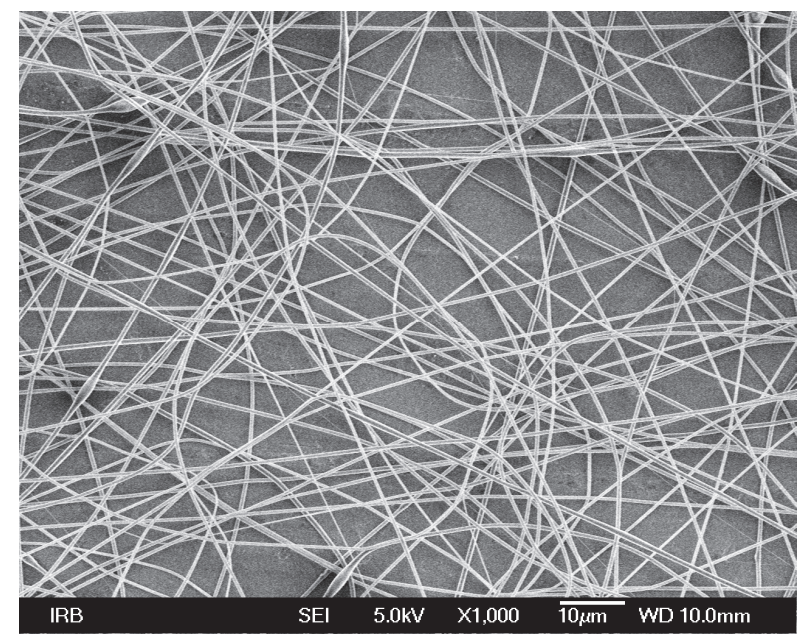

Figure 1. FE-SEM image of fibers produced by electrospinning of a viscous solution of $\mathrm{PVP}$ in $\mathrm{C}_{2} \mathrm{H}_{5} \mathrm{OH} / \mathrm{H}_{2} \mathrm{O}$ solvent (sample $\mathrm{S} 1$ ). 

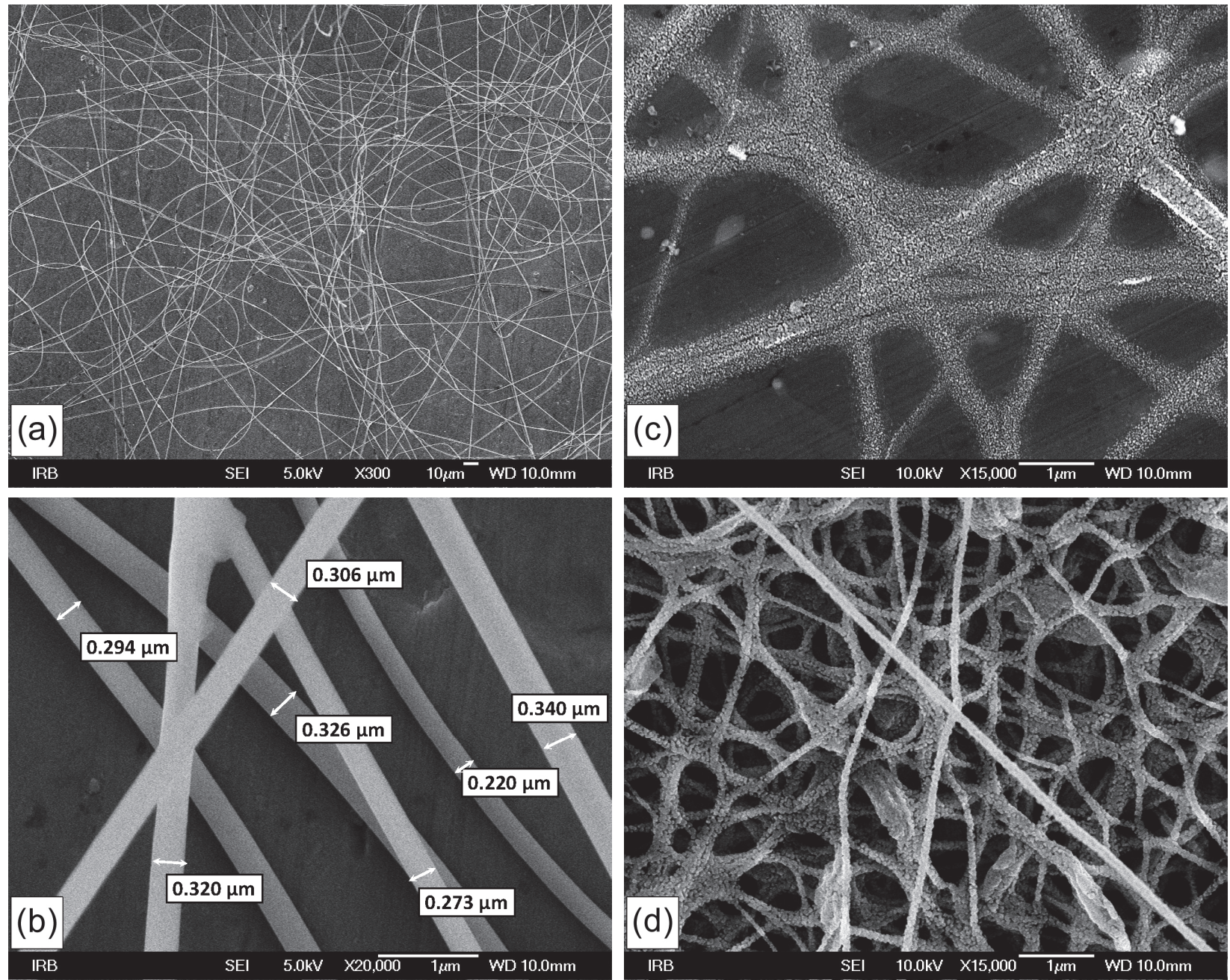

Figure 2. FE-SEM images of: sample S2 (a), sample S2 at higher optical magnification (b), sample S2-400 showing fibers consisting of uniform $\mathrm{ZnO}$ nanoparticles (c), and sample S2-500 showing fibers also consisting of $\mathrm{ZnO}$ nanoparticles (d).

$\mathrm{ZnO}$ fibers. Figure 6 shows the XRD pattern of particles produced at $600{ }^{\circ} \mathrm{C}$ (sample S2-600) which can be assigned to a hexagonal $\mathrm{ZnO}$ phase (wurtzite-type structure, space group $P 6_{3} m c(186) ; a=0.3249 \mathrm{~nm}, c=$ $0.5206 \mathrm{~nm}$; JCPDS card No. 36-1451).

Figure 7 shows the FT-IR spectrum of sample S2600. The spectrum can be assigned to $\mathrm{ZnO}$ taking into account the result of XRD characterization of the same sample. The FT-IR spectrum of sample S2-600 is characterized by an IR band at $444 \mathrm{~cm}^{-1}$ and a pronounced shoulder at $486 \mathrm{~cm}^{-1}$. According to Hayashi et al. ${ }^{20} \mathrm{ZnO}$ shows three distinct absorption peaks located between the bulk TO-phonon frequency $\left(\mathrm{C} \omega_{\mathrm{TII}}\right)$ and the LOphonon frequency $\left(\mathrm{C} \omega_{L} \perp\right)$. The absorption peaks shifted towards lower frequencies when the permittivity of the surrounding medium was increased. The IR spectrum of $\mathrm{ZnO}$ particles may vary from a very broad single band over a doublet up to a three-band superposition. ${ }^{21}$ The feature of the IR spectrum of $\mathrm{ZnO}$ depends on the geometrical shape of the particles. ${ }^{22}$ Pandiyarajan et al. ${ }^{23}$ prepared $\mathrm{ZnO}$ by crystallizing the gel formed by adding the $\mathrm{NaOH}$ solution to the $\mathrm{Zn}\left(\mathrm{NO}_{3}\right)_{2}$ solution. The FT-IR spectrum displayed an IR band at $444 \mathrm{~cm}^{-1}$. The IR band recorded at $454 \mathrm{~cm}^{-1}$ was red shifted up to $427 \mathrm{~cm}^{-1}$ when $\mathrm{ZnO}$ was doped ${ }^{24}$ with $10 \%$ Co. Kansal et al. ${ }^{25}$ synthesized $\mathrm{ZnO}$ particles using the hydrothermal procedure and the corresponding FT-IR spectrum displayed an IR band positioned at $\sim 478 \mathrm{~cm}^{-1}$. Sui et al. ${ }^{26}$ syntesized hexagonal $\mathrm{ZnO}$ prisms using a microemulsion containing PVP and these particles showed IR bands at $460-500 \mathrm{~cm}^{-1}$ due to $\mathrm{Zn}-\mathrm{O}$ band vibration.

Samples S2-400, S2-500 and S2-600 were also investigated using Raman spectroscopy. Generally, this technique is very useful in the characterization of metal oxide particles and specifically their surfaces. Damen et $a l .{ }^{27}$ interpreted the Raman spectrum of $\mathrm{ZnO}$. Two $E_{2}$ vibrations at 101 and $437 \mathrm{~cm}^{-1}$, one transverse $A_{1}$ at 381 $\mathrm{cm}^{-1}$ and one transverse $E_{1}$ at $407 \mathrm{~cm}^{-1}$, one longitudinal $A_{1}$ at $574 \mathrm{~cm}^{-1}$ and one longitudinal $E_{1}$ at $583 \mathrm{~cm}^{-1}$ were reported. Ristic et $a l^{4}{ }^{4}$ recorded the Raman spectra of 

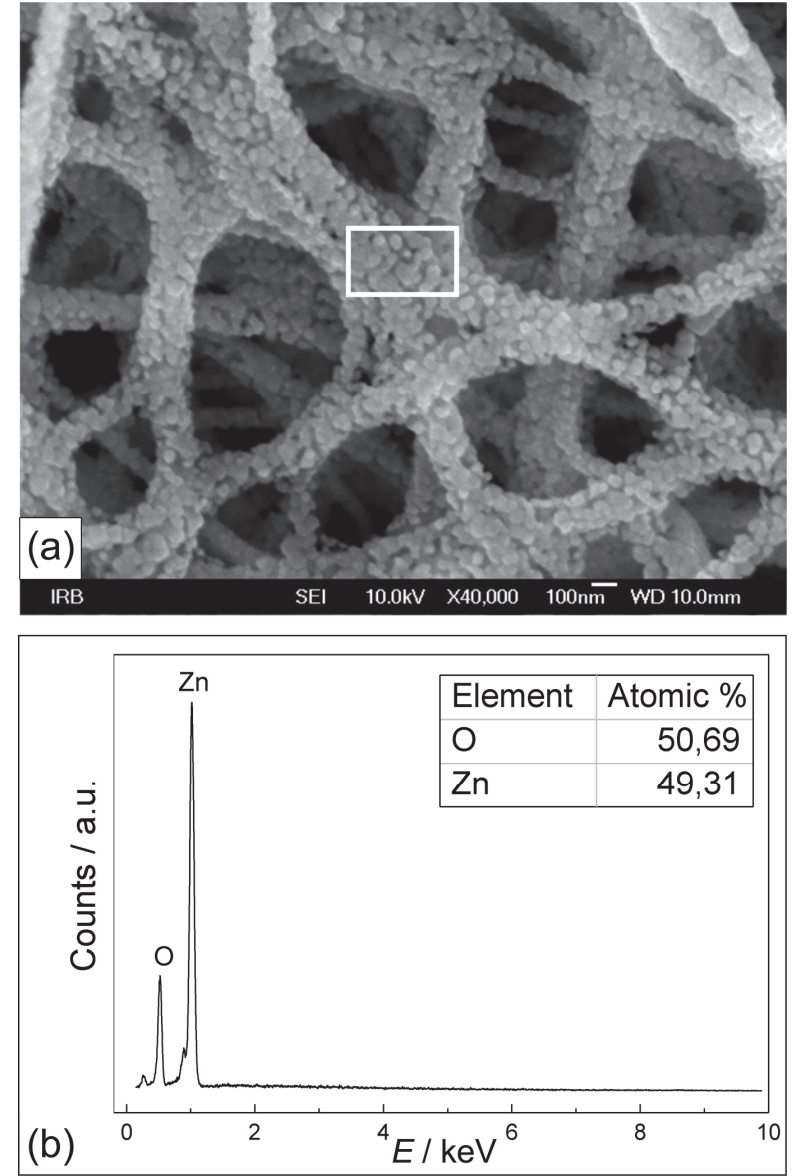

Figure 3. FE-SEM image of sample S2-500 at higher optical magnification (a) and EDS spectrum of selected area showing the atomic composition close to stoichiometric ratio $\mathrm{Zn}: \mathrm{O}$ in $\mathrm{ZnO}(\mathrm{b})$.

$\mathrm{ZnO}$ nanoparticles produced by the sol-gel procedure and found differences in relation to the Raman spectrum of large $\mathrm{ZnO}$ particles. The Raman band at $392 \mathrm{~cm}^{-1}$ recorded for $\mathrm{ZnO}$ nanoparticles was noticed at $381 \mathrm{~cm}^{-1}$ with large $\mathrm{ZnO}$ particles. The Raman band at $407 \mathrm{~cm}^{-1}$ noticed with large $\mathrm{ZnO}$ particles was shifted to $418 \mathrm{~cm}^{-1}$ with $\mathrm{ZnO}$ nanoparticles. The increase in relative intensities for the Raman band at $580 \mathrm{~cm}^{-1}$ and the shoulder at $542 \mathrm{~cm}^{-1}$, including the broadening, was likewise assigned to $\mathrm{ZnO}$ nanoparticles. The effect of very fine $\mathrm{SnO}_{2}$ particles and their aggregation were included in the investigation of the corresponding Raman spectrum. ${ }^{28}$ Zhao et al. ${ }^{29}$ prepared In-doped $\mathrm{ZnO}$ particles of different morphologies and detected an influence of Indoping on the feature of the Raman spectra. Stanković et al. ${ }^{30}$ investigated $\mathrm{ZnO}$ particles with Raman spectroscopy and the specific features in the spectra were attributed to the presence of structural defects (oxygen vacancies and zinc interstitials).

The Raman spectra of samples S2-400 and S2-500 (white films) are shown in Figure 8. These Raman spectra correspond to a pure $\mathrm{ZnO}$ phase.

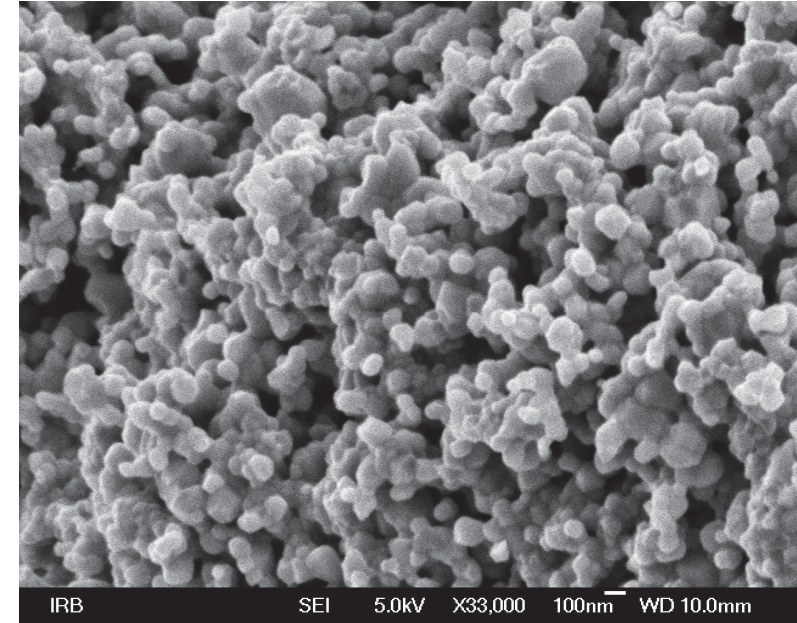

Figure 4. FE-SEM image of $\mathrm{ZnO}$ nanoparticles (sample S2-600) produced by heating sample $\mathrm{S} 2$ at $600{ }^{\circ} \mathrm{C}$ for $6 \mathrm{~h}$.
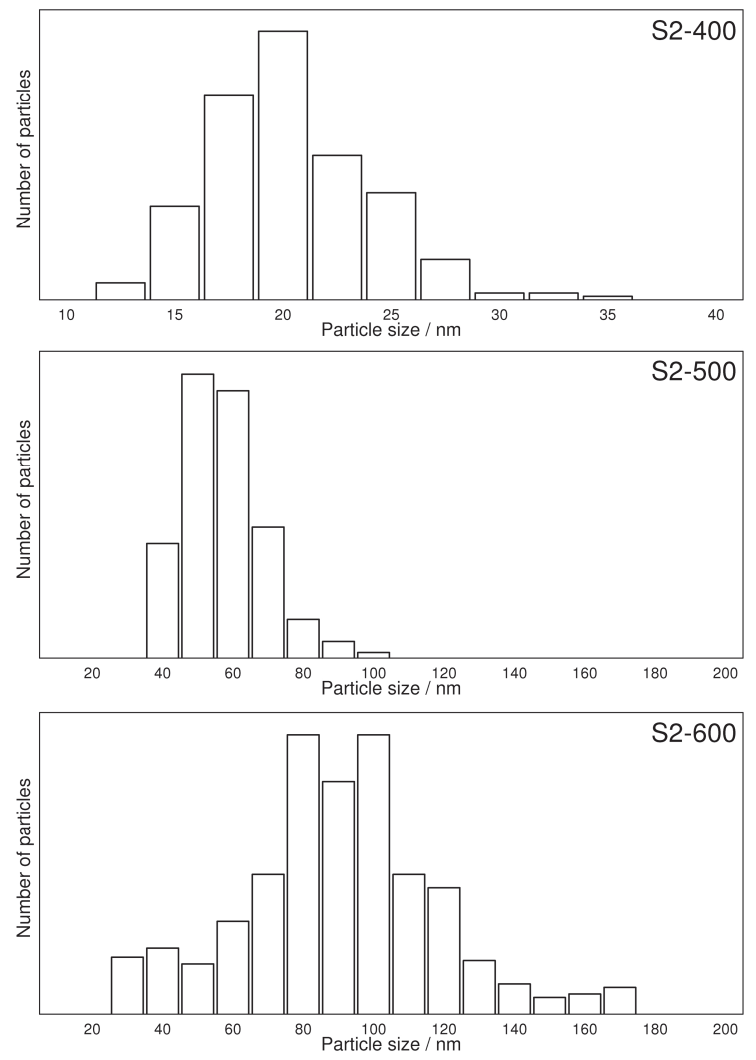

Figure 5. Size distributions of $\mathrm{ZnO}$ nanoparticles produced upon heating sample S2 at $400{ }^{\circ} \mathrm{C}$ (sample S2-400), $500{ }^{\circ} \mathrm{C}$ (sample S2-500) and $600^{\circ} \mathrm{C}$ (sample S2-600).

The Raman spectrum of sample S2-600 is shown in Figure 9. Shown in the same figure are the Raman spectra of commercial $\mathrm{ZnO}$ and graphite as reference materials. In the spectral range recorded between 10 and $800 \mathrm{~cm}^{-1}$ all observed Raman bands are typical of a 


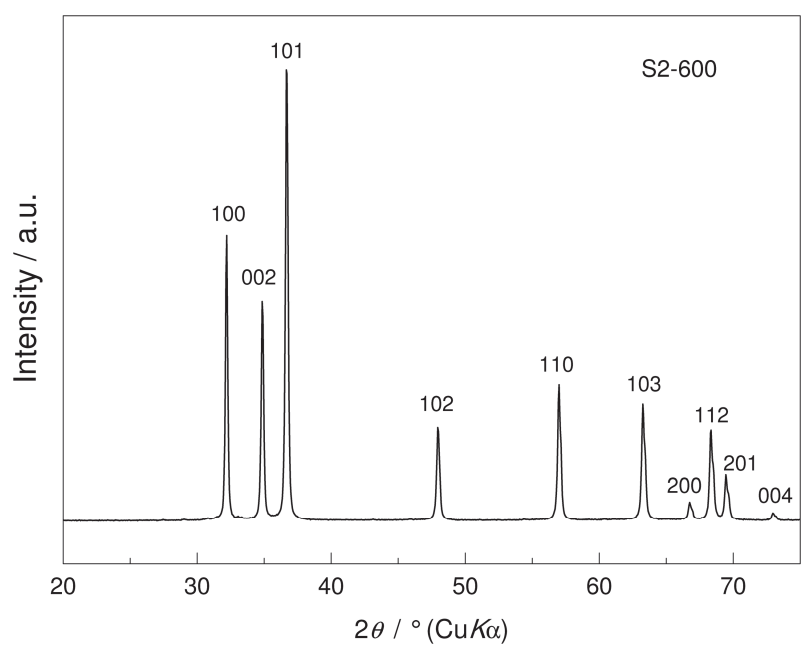

Figure 6. XRD pattern of sample S2-600.

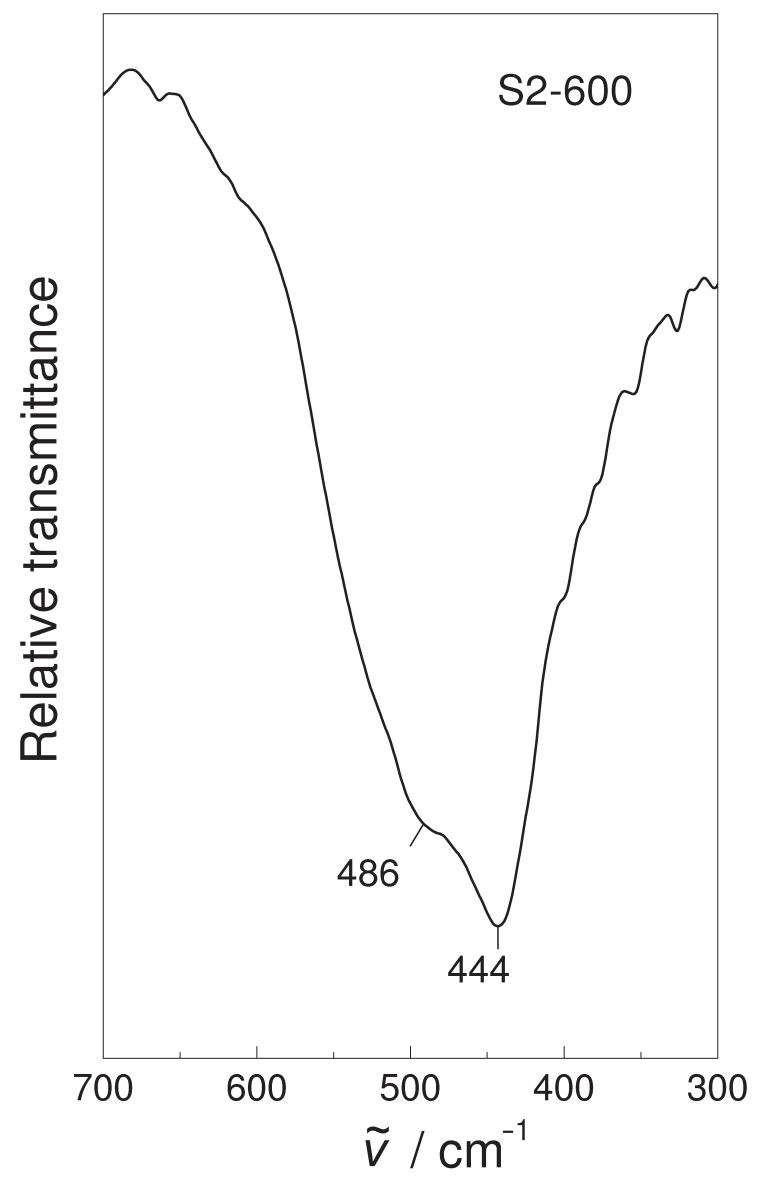

Figure 7. FT-IR spectrum of sample S2-600.

$\mathrm{ZnO}$ phase and their assignations are in line with the previous discussion. The Raman band in the spectral range $993-1152 \mathrm{~cm}^{-1}$ can be interpreted as the first harmonics of fundamental $A_{1}(\mathrm{LO})$ vibrations between 534 to $659 \mathrm{~cm}^{-1}$ and centered at $581 \mathrm{~cm}^{-1}$ in the present

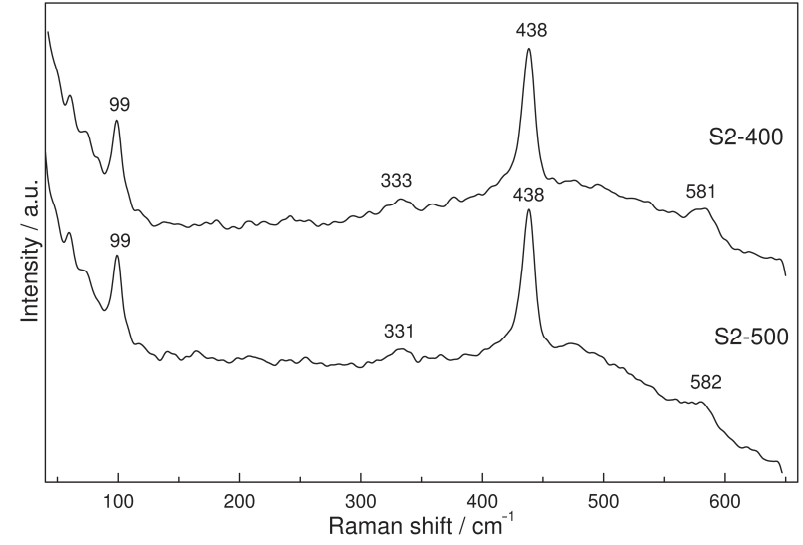

Figure 8. Raman spectra of samples S2-400 and S2-500.

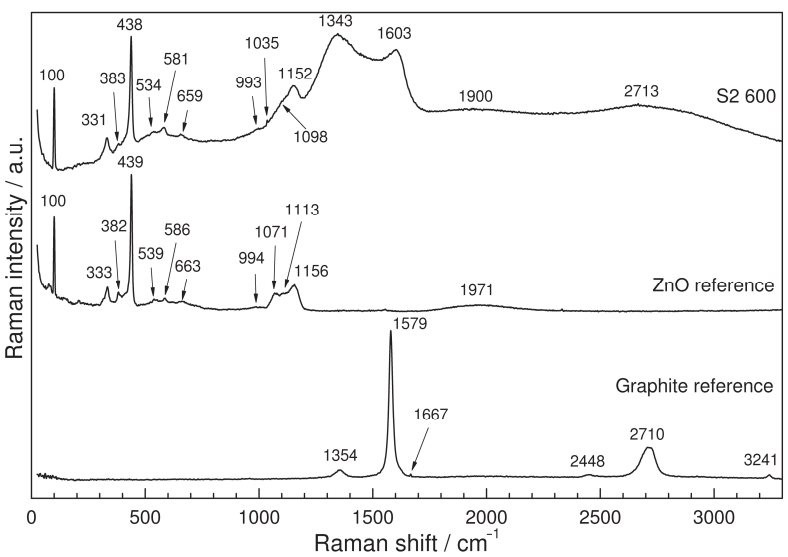

Figure 9. Raman spectrum of sample S2-600. Raman spectra of commercial $\mathrm{ZnO}$ and graphite as reference materials are also shown.

case. However, the spectrum of sample S2-600 additionally showed very broad bands at 1343, 1603 and $2713 \mathrm{~cm}^{-1}$ which are not present in reference $\mathrm{ZnO}$ (commercial sample). Since the precursor of the sample S2-600 was a thick deposit, a possibility of carbon formation during the calcination of PVP containing fibers was supposed.. The $\mathrm{ZnO}$ particles of sample S2-600, obtained by heating of the thick layer of their precursor, were white-gray and this was additional motivation to inspect their surface nature. However, the formation of graphite as the main carbon-containing phase is less likely, because the XRD pattern of sample S2-600 (Figure 5) showed no intensive diffraction line (002) of graphite at $2 \theta \sim 26.4^{\circ}$. It is more likely that the formation of graphene oxide $(\mathrm{GO})$ is dominant due to the thick precursor deposit and the calcining conditions.

Generally, graphene possesses a two-dimensional (2D) structure consisting of $\mathrm{sp}^{2}$ carbon network with one atom thickness. The Raman band at $1343 \mathrm{~cm}^{-1}$ is often interpreted as a disorder-induced $\mathrm{D}$ band, whereas the one at $1603 \mathrm{~cm}^{-1}$ as a graphite band (G). The D band 


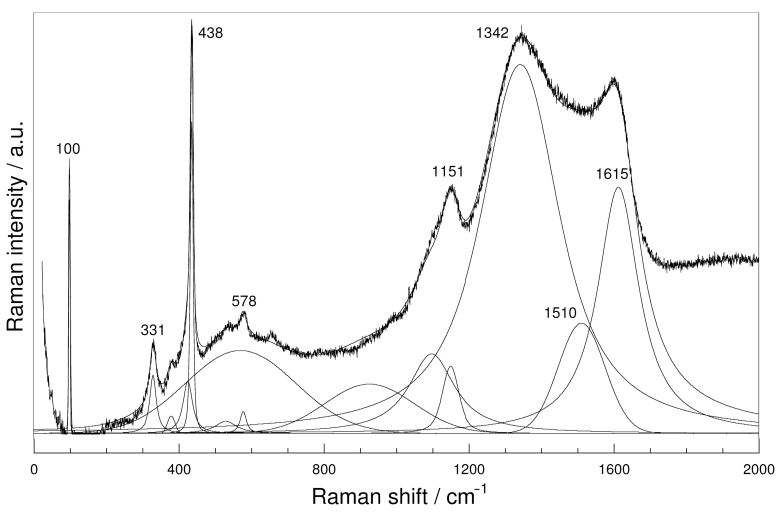

Figure 10. Deconvolution of D (disorder) and G (graphite) Raman bands, characteristic of graphene oxide (GO).

originates from structural imperfections, as $A_{1 \mathrm{~g}}$ mode, and the $\mathrm{G}$ band is the first-order scattering in the $E_{2 \mathrm{~g}}$ vibrational mode in graphite sheets. Due to the shape of D and G Raman bands, shown in Figure 9, they were resolved into three bands positioned at 1342, 1510, and $1615 \mathrm{~cm}^{-1}$ (Figure 10). Evidently, the features of D and $\mathrm{G}$ Raman bands, as well as the band $\mathrm{D}^{\prime}$ at $1510 \mathrm{~cm}^{-1}$, in the present case show a distribution of disorders in more GO layers with different participation of the carbonoxygen bond. This conclusion is supported by the presence of a very broad Raman band centered at $2713 \mathrm{~cm}^{-1}$ (2D, D $+\mathrm{G}, 2 \mathrm{G}$ superposition).

\section{CONCLUSION}

- Electrospinning of a viscous suspension containing PVP and zinc acetate in $\mathrm{C}_{2} \mathrm{H}_{5} \mathrm{OH} / \mathrm{H}_{2} \mathrm{O}$ produced several hundred $\mu \mathrm{m}$ long fibers (precursor fibers)

- Fibers consisted of $\mathrm{ZnO}$ nanoparticles were obtained on heating a thin deposit of precursor fibers at 400 or $500^{\circ} \mathrm{C}$ for $1 \mathrm{~h}$

- No $\mathrm{ZnO}$ fibers were obtained on heating a thick deposit of precursor fibers at $600{ }^{\circ} \mathrm{C}$ for $6 \mathrm{~h}$

- $\mathrm{ZnO}$ nanoparticles with a gradual increase in size were produced at all three heating temperatures $(400,500$ or $600{ }^{\circ} \mathrm{C}$ )

- The Raman spectrum of $\mathrm{ZnO}$ nanoparticles formed at $600{ }^{\circ} \mathrm{C}$ showed additional bands which were assigned to graphene oxide. The organic component in a thick deposit of precursor fibers did not burn out completely at $600{ }^{\circ} \mathrm{C}$ and the residual carbon (graphite) transformed into graphene oxide film onto $\mathrm{ZnO}$ particles for the experimental conditions applied.

Acknowledgements. Financial support by the Croatian Centre of Excellence for Advanced Materials and Sensing Devices is gratefully acknowledged.

\section{REFERENCES}

1. S. Musić, S. Popović, M. Maljković, and Đ. Dragčević, J. Alloys Comp. 347 (2002) 324-332.

2. S. Musić, Đ. Dragčević, M. Maljković, and S. Popović, Mater. Chem. Phys. 77 (2002) 521-530.

3. S. Musić, Đ. Dragčević, S. Popović, and M. Ivanda, Mater. Lett. 59 (2005) 2388-2393.

4. M. Ristić, S. Musić, M. Ivanda, and S. Popović, J. Alloys Comp. 397 (2005) L1-L4.

5. S. Musić, Đ. Dragčević, and S. Popović, J. Alloys Comp. 429 (2007) 242-249.

6. S. Musić, A. Šarić, and S. Popović, J. Alloys Comp. 448 (2008) 277-283.

7. S. Musić, A. Šarić, and S. Popović, Ceramics Int. 36 (2010) $1117-1123$.

8. A. Šarić, S. Musić, and M. Ivanda, J. Mol. Struct. 993 (2011) 219-224.

9. S. Musić and A. Šarić, Ceramics Int. 38 (2012) 6047-6052.

10. C. Lee, S.-W. Park, Y. Jae, and S. S. Kim, Sensor Lett. 9 (2011) 132-136.

11. O.-K. Kim, H. Kim, and D. Kim, Korean J. Mater. Res. 22 (2012) 609-614.

12. M. Zhao, X. Wang, L. Ning, J. Jia, X. Li, and L. Cao, Sensors and Actuators B 156 (2011) 588-592.

13. M. Zhao, X. Wang, J. Cheng, L. Zhang, J. Jia, and X. Li, Current Appl. Phys. 13 (2013) 403-407.

14. X. Wang, M. Zhao, F. Liu, J. Jia, X. Li, and L. Cao, Ceramics Int. 39 (2013) 2883-2887.

15. J. Y. Park, J. J. Kim, and S. S. Kim, Microelectron. Eng. 101 (2013) 8-11.

16. Y. Shmueli, G. E. Shter, O. Assad, H. Haick, P. Sontag, P. Ricoux, and G. S. Grader, J. Mater. Res. 27 (2012) 1672-1679.

17. M. Tanveer, A. Habib, and M. B. Khan, Mater. Sci. Eng. B 177 (2012) 1144-1148.

18. Z. Zhang, C. Shao, X. Li, C. Wang, M. Zhang, and Y. Liu, ACS Appl. Mater. Interfaces 2 (2010) 2915-2923.

19. S. Ramakrishna, K. Fujihara, W.-E. Teo, T.-C. Lim, and Z. Ma, An Introduction to Electrospinning and Nanofibers, World Scientific Publishing Co. Pte Ltd., Singapore, 2005., pp. 396.

20. S. Hayashi, N. Nakamori, H. Kanamori, Y. Yodogawa, and K. Yamamoto, Surf. Sci. 86 (1979) 665-671.

21. M. Andres-Vergés and S. J. Serna, J. Mater. Sci. Lett. 7 (1988) 970-972.

22. M. Andres-Vergés, A. Mifsud, and C. J. Serna, J. Chem. Soc., Faraday Trans. 86 (1990) 959-963.

23. T. Pandiyarajan, R. Udayabhaskar, and B. Karthikeyan, Appl. Phys. A 107 (2012) 411-419.

24. F. Ahmed, S. Kumar, N. Arshi, M. S. Anwar, B. H. Koo, and C. G. Lee, Microelectron. Eng. 89 (2012) 129-132.

25. S. K. Kansal, A. H. Ali, S. Kapoor, and D. W. Bahnemann, Sep. Purif. Technol. 80 (2011) 125-130.

26. X. Sui, Y. Liu, C. Shao, Y. Liu, and C. Xu, Chem. Phys. Lett. 424 (2006) 340-344.

27. T. C. Damen, S. P. S. Porto, and B. Tell, Phys. Rev. 142 (1966) 570-573.

28. M. Ristić, M. Ivanda, S. Popović, and S. Musić, J. Non-Cryst. Solids 303 (2012) 270-280.

29. J. Zhao, X. Yan, Y. Yang, Y. Huang, and Y. Zhang, Mater. Lett. 64 (2010) 569-572.

30. A. Stanković, Z. Stojanović, Lj. Veselinović, S. D. Škapin, I. Bračko, S. Marković, and D. Uskoković, Mater. Sci. Eng. B 177 (2012) 1038-1045. 